\title{
Salary Market Equity at the University of Colorado at Boulder Libraries: A Case Study Follow-up
}

\section{Scott Seaman, Carol Krismann, and Nancy Carter}

During the 1995-1996 academic year, the University of Colorado at Boulder Libraries received market equity funds to increase librarian salaries to the median Association of American University librarian salary. One stipulation of the university administration required that the market equity funds be distributed over four years rather than in a single year. In an earlier article, the authors predicted that, as result of spreading the increase over four years, salaries of libraries faculty would only reach the 1996-1997 mean in 2000-2001. This follow-up study analyzes the results of distributing the equity funds over the four years between 1995-1996 and 20002001. It finds that during that time, the University of Colorado at Boulder Libraries rose from the bottom quartile of its comparison group to the top quartile when ranked by median salary, suggesting that spreading the equity over four years did not significantly impact the final salaries. Detailed analysis, however, reveals that although the overall salary pool rose in its comparison group, many individual librarians' salaries did not reach market. This study concludes that the increase in overall ranking was due to a fundamental change in the profile of the faculty rather than to the application of market equity funds. The failure of some salaries to increase to market can likely be attributed to changes in the market rate of each position classification. Further, although the application of market equity might have been improved had the distances between the market and the librarians' salaries been recalculated each of the four years, internal and external factors may have made that impractical.

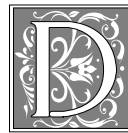

uring the 1995-1996 academic year, the University of Colorado at Boulder Libraries (CUB) received market equity funds for librarian salaries. The justification process used statistics generated by the Association of Research Libraries (ARL) to demonstrate an overall $\$ 298,270$ salary deficit between the University Libraries salaries and the peer group of the twenty-nine Association of American University (AAU) public institutions. This process was described in a July 2000 Journal of Academic Librarianship $(J A L)$ article. ${ }^{1}$ In awarding the monies to

Scott Seaman is Associate Director for Administrative Services in the University Libraries at the University of Colorado at Boulder; e-mail: seaman@spot.colorado.edu. Carol Krismann is Head of the White Business Library at the University of Colorado at Boulder; e-mail: carol.krisman@colorado.edu. Nancy Carter is Head of the Lester Math-Physics Library at the University of Colorado at Boulder; e-mail: nancy.carter@colorado.edu. 
address the problem, however, the university administration stipulated some conditions. Those conditions were that equity increases were to be position specific rather than divided equally, that individual increases were to be based partly on past merit, and that the award of $\$ 300,000$ was to be paid over four years at $\$ 75,000$ per year. These stipulations greatly complicated the awarding of individual increases.

The purpose of this article is to revisit the salaries of the University Libraries faculty after all market equity awards had been made to determine whether the conclusion drawn in the July 2000 JAL article was valid. It was stated in the conclusion of that earlier article that because of the four-year delay in awarding all the money, after the fourth and final increment in 2000-2001, salaries of University Libraries faculty would be at the 1996-1997 mean instead of at the 2000-2001 mean of AAU public institutions. The necessity of distributing the equity increase over a four-year period undermined the purpose of bringing this faculty up to the present-day AAU mean. Although this seemed the logical conclusion at the time, situations involving personnel often have too many variables to be easily predicted.

\section{Literature Review}

Salary market equity is achieved when local salaries approximate those of peers at comparable institutions. Not only does market equity acknowledge the moral, judicial, and economic equality of employees, it also recognizes that the ongoing health of an organization depends on paying fair market value to attract and retain qualified individuals. Although educational background and experience are often calculated into market values, specific circumstances such as individual merit are not considered-only what value the larger national or regional market places on the position.

Surprisingly, only a handful of libraryspecific articles have been published concerning market equity. Most library equity studies, as pointed out in the 2000 $J A L$ article, pertain to gender equity. Only two articles, Maureen Pastine and Shirley McLean's "Pay Equity in Libraries" and Jeanie Welch and Linda Dugger's "Suggested Guidelines for Salary Determination in an Academic Library," examined local salaries as they related to a national or regional market. ${ }^{2,3}$

Pastine and McLean's experience at Southern Methodist University (Texas) provided CUB Libraries a broad model on which to base an argument for market equity. The Southern Methodist University (SMU) experience was that its equity award, which was to be spread over three years, was eliminated after the first year due to campus budget cuts. This proved to be a cautionary note for CUB Libraries as the award was spread over four years. The Welch and Dugger study from Lamar University (Texas) in the mid-1980s used faculty rank to compare librarians' salaries with those of teaching faculty on the Lamar campus. This provided insight into how experience, educational background, position responsibility, and special skills could be calculated into market value for library positions. In addition, it gave CUB Libraries a basis on which to include merit in the individual market awards.

Most of the studies cited in the earlier $J A L$ article, however, came from academe outside librarianship. Although the literature demonstrates a wide variety of approaches to identify, calculate, and apply market equity, there are no studies—at least within higher education - that analyze the impact of market equity. No follow-up articles have been published to determine whether that particular method successfully addressed the articulated problem.

\section{Market History}

For much of the early 1990s, librarians' salaries stagnated as the national economy endured a deep recession. Higher education confronted cutbacks, library materials budgets were constrained, advertisements for vacant positions declined, and library schools were closing. ${ }^{4}$

In 1993, Library Journal reported that 20 percent of all recent library school graduates could not find full-time employment. 
By the mid-1990s, recent graduates were turning to nontraditional positions in the technology industry, such as Web design or online systems administration. ${ }^{5}$ Propelling this migration from librarianship was the average starting salary for nontraditional positions, which was 4.5 to 7.6 percent higher than traditional library positions. ${ }^{6}$ As recent graduates migrated toward careers in information technology, libraries gradually increased starting salaries; and in 1997, entry-level salaries surpassed \$30,000 for the first time. ${ }^{7}$ In 1996, the average librarian had realized a salary increase of less than one percent over the previous year, but between 1997 and 1998 , the average starting salary for all new hires was up 6.8 percent and then up another 4.4 percent in 1999 to $\$ 32,837.8$

Academic library salaries reflected the national market for librarians through the 1990s. The average ARL university library salary was $\$ 37,092$ in $1990 .{ }^{9}$ Throughout the mid-1990s, the average ARL salary increased by only two percent annually, and although by the late 1990 s that had increased to three to four percent annual increases, such increases barely kept pace with inflation. ${ }^{10}$ Consequently, during the late 1990s, many academic libraries focused limited resources on recruiting at the entry level. In 1994-1995, the median entry-level salary for ARL university librarians was $\$ 27,000$, but it climbed nearly 20 percent by $1999-2000$ to $\$ 31,100 .{ }^{11}$ That new placement salaries were rising quickly (and that existing salaries were unable to keep up) was noted in the ARL Annual Salary Survey 2000-2001, predicting a future of libraries "with fewer staff members, who in turn are being paid salaries that are fighting to keep up with inflation."12

At the University of Colorado at Boulder, salaries lagged behind the profession throughout the late 1980s and reached a crisis by the mid-1990s. The mean CUB Libraries' salary in 1991 was \$34,695, a deficit of 13 percent from the ARL mean of $\$ 39,310 .{ }^{13}$ By the $1995-1996$ academic year, the deficit had increased to 17 percent. ${ }^{14}$ With retention nearly impossible and recruitment stalled, the campus implemented a four-year market equity plan to increase salaries.

\section{University of Colorado at Boulder}

The University of Colorado is a four-campus system with the flagship institution at its Boulder campus. The Boulder campus is a Carnegie I research institution supported by a university libraries system consisting of a main library and five subjectspecialized external branch libraries. University Libraries is a member of the ARL, with total holdings of 2,600,000 books and 18,400 serial subscriptions. In addition, there is an autonomous law library that was not included in the market equity process.

At the time of the market equity study and award, there were fifty-five librarians. Boulder campus librarians have faculty status, including significant research, publication, and service responsibilities. Governance within the University Libraries is managed by the libraries' faculty. The Faculty Personnel Committee (FPC), one of five elected faculty governance committees, annually reviews faculty activity in research and service, assesses internal salary equity, and recommends both compensation awards and internal equity adjustments to the dean of University Libraries. The FPC played a significant role in the distribution of market equity funds. The executive committee of the libraries, the Cabinet, is composed of the dean of University Libraries and three associate directors. The Cabinet works closely with the libraries' FPC on matters of personnel evaluation and salary allocation. The FPC recommends annual faculty salary increases to the dean, who has final responsibility for all decisions.

The University of Colorado at Boulder's comparison group is considered to be the Association of American Universities (AAU), a group of sixty-two North American research universities. A subset of twenty-nine of the AAU are public institutions, and it is with that group the University of Colorado is routinely compared.${ }^{15}$ All twenty-nine institutions, including the University of Colorado at Boulder, are members of the ARL. The salary analysis for this study was generated from the ARL's 


\begin{tabular}{|c|c|c|c|c|c|}
\hline University of & $\begin{array}{l}\text { Estimatin } \\
\text { Colorado at I } \\
\end{array}$ & $\begin{array}{r}\text { T } \\
\text { Marl } \\
\text { Soulder } \\
\text { All Posi }\end{array}$ & $\begin{array}{l}\text { BLE } 1 \\
\text { et Inequity by } \\
\text { arsus Public AAU } \\
\text { ons, 1996-1997 }\end{array}$ & $\begin{array}{l}\text { Position } \\
\text { Libraries Mean }\end{array}$ & Salaries \\
\hline $\begin{array}{l}\text { Position } \\
\text { Classification }\end{array}$ & $\begin{array}{c}\text { CUB } \\
\text { Mean } \\
\text { Salary } \\
\text { 1996-1997 }\end{array}$ & $\begin{array}{l}\text { CUB } \\
\text { FTE }\end{array}$ & $\begin{array}{l}\text { AAU Public } \\
\text { Mean Salary } \\
\text { 1996-1997 }\end{array}$ & $\begin{array}{c}\text { CUB Distance } \\
\text { Below or } \\
\text { (Above) AAU } \\
\text { Public Mean }\end{array}$ & $\begin{array}{c}\text { CUB FTE } \\
\text { by CUB } \\
\text { Distance }\end{array}$ \\
\hline Associate Director & $\$ 63,473$ & 3 & $\$ 76,282$ & $\$ 12,809$ & $\$ 38,426$ \\
\hline Head, Branch & $\$ 45,743$ & 4 & $\$ 51,989$ & $\$ 6,246$ & $\$ 24,985$ \\
\hline Functional Specialist & $\$ 34,614$ & 4 & $\$ 41,735$ & $\$ 7,121$ & $\$ 28,486$ \\
\hline Department Head & & & & & \\
\hline Acquisitions & $\$ 49,734$ & 1 & $\$ 51,171$ & $\$ 1,437$ & $\$ 1,437$ \\
\hline Reference & $\$ 45,918$ & 1 & $\$ 52,524$ & $\$ 6,606$ & $\$ 6,606$ \\
\hline Cataloging & $\$ 41,376$ & 3 & $\$ 48,942$ & $\$ 7,567$ & $\$ 22,700$ \\
\hline Serials & $\$ 47,948$ & 1 & $\$ 53,146$ & $\$ 5,198$ & $\$ 5,198$ \\
\hline Documents & $\$ 43,230$ & 1 & $\$ 48,704$ & $\$ 5,474$ & $\$ 5,474$ \\
\hline Circulation & $\$ 45,357$ & 1 & $\$ 49,627$ & $\$ 4,270$ & $\$ 4,270$ \\
\hline Rare Books & $\$ 45,721$ & 1 & $\$ 57,900$ & $\$ 12,179$ & $\$ 12,179$ \\
\hline Computer Systems & $\$ 42,219$ & 1 & $\$ 54,356$ & $\$ 12,137$ & $\$ 12,137$ \\
\hline Other & $\$ 43,075$ & 6 & $\$ 49,487$ & $\$ 6,412$ & $\$ 38,470$ \\
\hline Reference Librariar & & & & & \\
\hline Over 14 Years Exp. & $\$ 38,409$ & 7 & $\$ 44,531$ & $\$ 6,121$ & $\$ 42,848$ \\
\hline 10-14 Years & $\$ 30,164$ & 2 & $\$ 37,930$ & $\$ 7,766$ & $\$ 15,532$ \\
\hline 5-9 Years & $\$ 32,453$ & 3 & $\$ 34,619$ & $\$ 2,166$ & $\$ 6,499$ \\
\hline Under 5 Years & $\$ 29,040$ & 2 & $\$ 30,295$ & $\$ 1,256$ & $\$ 2,511$ \\
\hline Cataloging Libraria & & & & & \\
\hline 10-14 Years & $\$ 33,614$ & 2 & $\$ 39,549$ & $\$ 5,935$ & $\$ 11,871$ \\
\hline 5-9 Years & $\$ 32,754$ & 2 & $\$ 35,794$ & $\$ 3,040$ & $\$ 6,080$ \\
\hline Under 5 Years & $\$ 27,727$ & 4 & $\$ 29,680$ & $\$ 1,954$ & $\$ 7,814$ \\
\hline Other Librarian & & & & & \\
\hline Over 14 Years Exp. & $\$ 42,761$ & 1 & $\$ 47,510$ & $\$ 4,749$ & $\$ 4,749$ \\
\hline $10-14$ Years & $\$ 41,641$ & 1 & $\$ 40,230$ & $(\$ 1,411)$ & $(\$ 1,411)$ \\
\hline Total & & 51 & & & $\$ 296,861$ \\
\hline
\end{tabular}

Annual Salary Survey by extracting the data of the twenty-nine AAU institutions.

\section{Market Equity Goals}

In the 1995-1996 academic year, University Libraries successfully justified to the CUB's Academic Affairs Budget Advisory Committee (AABAC) the need for $\$ 300,000$ in market equity for fifty-one librarians. This justification was based on the comparative salary data from the twenty-nine
AAU institutions that demonstrated CUB Libraries salaries ranked in the bottom 20 percent of the group. Table 1 summarizes the estimated market need in 1996-1997. At the request of AABAC for comparative service data, charts were provided indicating that University Libraries was among the top service providers in the AAU, as measured by per-student activity in such areas as volumes circulated, reference questions answered, and interlibrary loans 
borrowed. The combination of low salaries and high service activity persuaded AABAC to fund $\$ 300,000$ in market equity.

The goal of the market equity application was to raise the overall libraries' faculty salaries to the 1996-1997 AAU market in order to improve recruitment and retention. But due to campus budget constraints, the $\$ 300,000$ equity adjustment was spread over four years. Beginning in the 1996-1997 year, $\$ 75,000$ was to be applied to library salaries each year, ending in 2000-2001. Dividing the funds over four years, rather than awarding everything in 1996-1997, saved the campus approximately $\$ 450,000$ over the life of the project. That is, $\$ 75,000$ was distributed in the first year rather than $\$ 300,000$, saving the campus $\$ 225,000$ in the first year. In the second year, another $\$ 75,000$ was distributed, saving the campus $\$ 150,000$. In the third year, $\$ 75,000$ was distributed, saving the campus $\$ 75,000$. This totaled a one-time saving of $\$ 450,000$ for the campus. More important, however, it was more palatable to skim $\$ 75,000$ each year from campus compensation awards than to absorb a single large hit for one department. Although University Libraries was grateful for the salary infusion, there was concern that by spreading the equity over four years, salaries would never catch up to the AAU market. In fact, the July 2000 JAL article predicted that "spreading the increase over four years would not bring salaries to the 1995-1996 mean until the academic year of 1999-2000."16

\section{Market Equity Constraints}

Because the campus did fund all four years of the market equity increase, the FPC applied equity increases to individual faculty in a manner consistent with a process described in the July $2000 J A L$ article throughout the four years. Of the fifty-five librarians rostered, fifty-one were eligible for market equity. The total equity was calculated and distributed, based on individual distances from the market mean and a minor adjustment for merit, in equal amounts over the four years. Although the equity awards varied greatly among individual librarians, the division and its application were generally perceived by University Libraries faculty as rational and impartial.

Although funded over the four years, the campus did not provide the full $\$ 300,000$. A subtle, but far-reaching, provision imposed a restriction over the distribution of market equity funds. As faculty lines became vacant, the campus would no longer award market equity to that position. Instead, University Libraries was expected to hire those positions at AAU market, making up the market difference from the libraries' own resources. During the four years of the equity program, twenty of the fifty-one eligible faculty retired or left for other positions. As University Libraries recruited for those vacancies, the new librarians were hired at AAU market for the position and were not eligible for further market equity. These vacancies decreased the total campus obligation from $\$ 300,000$ to $\$ 265,767$ - significantly less than anticipated.

Self-funding vacant positions to AAU market levels quickly became a burden for the libraries. Often positions were $\$ 7,000$ to $\$ 12,000$ below market, and the libraries did not have funds to increase salaries at recruitment. University Libraries, instead, focused its strategy on hiring almost exclusively at entry level. Although there were not enough funds to hire mid- or senior-career librarians at market rates, there were funds in each line to hire at entry level. Of the twenty recruitments, fifteen position descriptions were altered and salaries reduced to AAU entry-level market salaries. In some cases, these amounted to substantial alterations to the position descriptions; in other cases, they were already at entry level. Salary savings from the entry-level hires were invested in the remaining four hiresmidcareer department head positionspermitting them to be hired at the AAU market for those positions. An unintended consequence of this mandate, then, was to drive the libraries' recruiting policy towards entry-level hires that could be made at the AAU market rate. 


\section{Market Equity Analysis}

Figure 1 illustrates how, after being below AAU market for much of the 1990s, CUB Libraries salaries made significant gains as equity money was applied and even exceeded AAU market in the 1998-1999 academic year. In 1995, CUB Libraries ranked twenty-fifth in median salary of the twentyeight reporting AAU public institutions. By 2001-2002, a year after the market equity process was completed, CUB ranked seventh of twenty-nine. Between 1995 and 2001, CUB Libraries moved from the bottom quartile of its comparison group to the top quartile when ranked by median salary. By 2001-2002, the mean CUB librarian's salary was $\$ 54,251$ - slightly above the AAU mean of $\$ 52,923 .{ }^{17}$ Of course, the Boulder campus and CUB Libraries consider this a tremendous success. Moreover, it seems to indicate that the speculation of the July 2000 JAL article — that CUB salaries would only reach the 1995-1996 AAU mean by 1999-2000 — was incorrect. But there remain troubling shortcomings to such glossy data. Understanding the limitations could benefit other institutions implementing market equity over time.

In 1996-1997, fifty-one librarians were eligible for market equity. During the fouryear program, twenty librarians left University Libraries, and most of these were replaced with entry-level hires at the AAU market salary. In a typical instance, a reference librarian retired who had more than fourteen years of experience and was earning $\$ 4,200$ below AAU market. This faculty member was replaced by a librarian with less than five years of experience earning $\$ 2,000$ above market. What was a $\$ 4,200$ market deficit became a $\$ 2,000$ market overage in the third year of the program without any additional funds being applied to the position. Such shifts happened for twenty of fifty-one positions. With thirtyeight percent of the libraries' positions being redefined to meet market at lower salaries than their 1996-1997 level, it is no surprise that overall faculty salaries rose to the AAU market level so quickly.

The median ranking data referred to above and the mean salary data used to create figure 1 include all occupied positions within the libraries. The nationally reported data from which this was extracted include both the faculty who continued throughout the program and the new hires made at above-market rates. What is being charted, therefore, is not a static faculty. Instead, the faculty changed dramatically during the four years by becoming younger and with lower salaries. Drawing conclusions based on the salaries of the entire 2001-2002 libraries

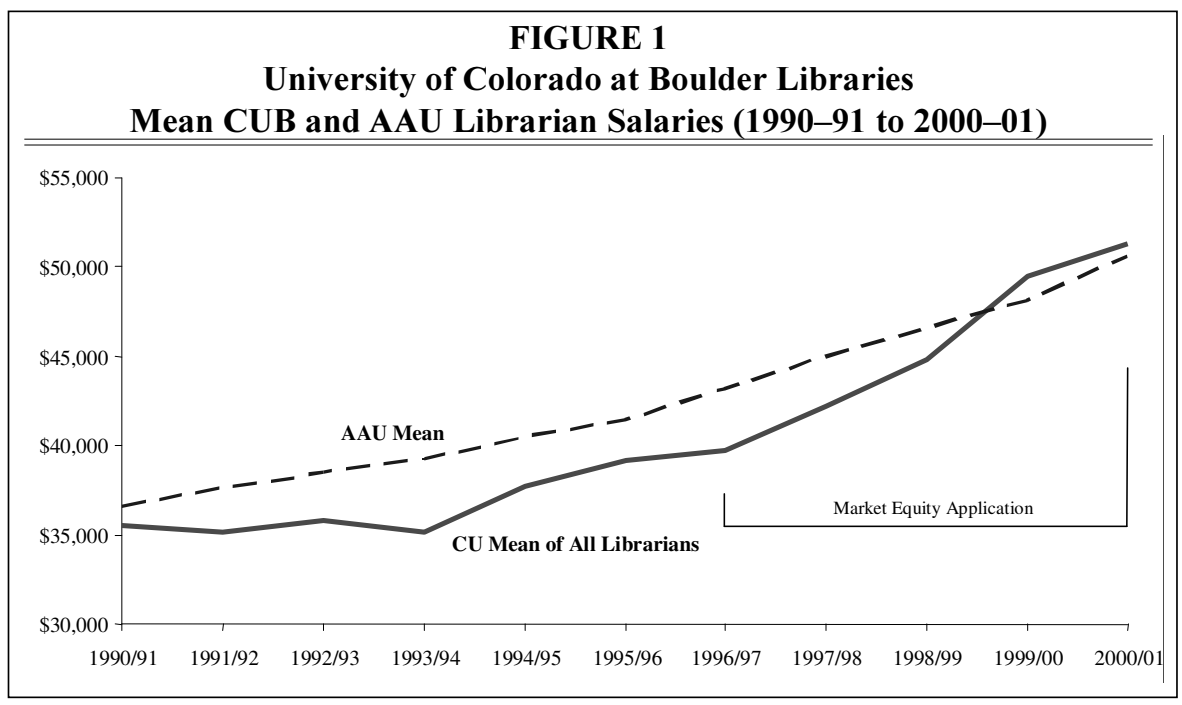


TABLE 2

Estimating Market Inequity by Position

University of Colorado at Boulder versus Public AAU Libraries Mean Salaries

Continuing Positions, 2000-2001

\begin{tabular}{|c|c|c|c|c|c|}
\hline $\begin{array}{l}\text { Position } \\
\text { Classification }\end{array}$ & $\begin{array}{c}\text { CUB } \\
\text { Mean } \\
\text { Salary } \\
\text { 2000-2001 }\end{array}$ & $\begin{array}{l}\text { CUB } \\
\text { FTE }\end{array}$ & $\begin{array}{l}\text { AAU Public } \\
\text { Mean Salary } \\
2000-2001\end{array}$ & $\begin{array}{c}\text { CUB Distance } \\
\text { Below or } \\
\text { (Above) AAU } \\
\text { Public Mean }\end{array}$ & $\begin{array}{c}\text { CUB FTE } \\
\text { by CUB } \\
\text { Distance }\end{array}$ \\
\hline Associate Director & $\$ 82,843$ & 3 & $\$ 93,526$ & $\$ 10,683$ & $\$ 32,049$ \\
\hline Head, Branch & $\$ 57,833$ & 5 & $\$ 61,661$ & $\$ 3,829$ & $\$ 19,143$ \\
\hline Functional Specialist & $\$ 48,481$ & 4 & $\$ 48,127$ & $(\$ 353)$ & $(\$ 1,414)$ \\
\hline \multicolumn{6}{|l|}{ Department Head } \\
\hline Acquisitions & $\$ 56,795$ & 1 & $\$ 61,873$ & $\$ 5,078$ & $\$ 5,078$ \\
\hline Reference & $\$ 62,113$ & 1 & $\$ 59,602$ & $(\$ 2,511)$ & $(\$ 2,511)$ \\
\hline Cataloging & $\$ 59,482$ & 1 & $\$ 57,872$ & $(\$ 1,610)$ & $(\$ 1,610)$ \\
\hline Documents & $\$ 54,976$ & 1 & $\$ 58,100$ & $\$ 3,124$ & $\$ 3,124$ \\
\hline Rare Books & $\$ 64,868$ & 2 & $\$ 73,611$ & $\$ 8,744$ & $\$ 17,487$ \\
\hline Computer Systems & $\$ 62,920$ & 1 & $\$ 70,959$ & $\$ 8,039$ & $\$ 8,039$ \\
\hline Other & $\$ 54,304$ & 3 & $\$ 57,471$ & $\$ 3,167$ & $\$ 9,501$ \\
\hline \multicolumn{6}{|l|}{ Reference Librarian } \\
\hline Over 14 Years Exp. & $\$ 50,732$ & 6 & $\$ 52,094$ & $\$ 1,362$ & $\$ 8,174$ \\
\hline 10-14 Years & $\$ 49,172$ & 1 & $\$ 44,909$ & $(\$ 4,263)$ & $(\$ 4,263)$ \\
\hline 5-9 Years & $\$ 44,962$ & 1 & $\$ 40,490$ & $(\$ 4,472)$ & $(\$ 4,472)$ \\
\hline \multicolumn{6}{|c|}{ Cataloging Librarian } \\
\hline Over 14 Years Exp. & $\$ 44,962$ & 1 & $\$ 50,167$ & $\$ 5,205$ & $\$ 5,205$ \\
\hline Total & & 31 & & & $\$ 93,530$ \\
\hline
\end{tabular}

faculty would ignore a fundamental shift in demographics.

When only the faculty who were employed throughout the equity program are examined, however, the impact of spreading the equity funds over four years becomes more apparent. Table 2 removes the twenty faculty who were hired midway through the program at market rates. The thirty-one remaining positions are those that continued throughout the entire four-year program. Table 2 compares their salaries at the end of the equity program to that year's 2000-2001 AAU mean. Most striking is that after four years and $\$ 265,000$ in funding, there remains over $\$ 93,000$ in market inequity for the continuing thirty-one positions.

Of the fourteen classifications of continuing librarians, nine did not achieve market equity. Several classifications did not even improve noticeably from the 1996-1997 status. The associate director classification was $\$ 12,809$ below the AAU mean in 1996-1997. After four years of market equity infusion, the classification was still $\$ 10,683$ below the mean in 2000 2001 . Even though nearly $\$ 13,000$ was added to those salaries over the four years, the associate directors only increased from 81 percent of the mean to 86 percent. Similarly, the head, branch classification was $\$ 6,246$ below the mean in 1996-1997 and was still $\$ 3,829$ below the AAU mean in 2000-2001. The classification had risen from 86 percent of the AAU mean to 93 percent. Other positions were in a similar predicament. The head of computer systems classification had gone from 84 percent of the mean in 1996-1997 to only 89 
percent of the mean in 2000-2001. The rare books librarian classification had risen only two percent, from 86 percent in 19961997 to 88 percent in 2000-2001. Astonishingly, the department head acquisitions classification actually went from $\$ 1,437$ below the AAU mean in 1996-1997 to
$\$ 5,078$ below the mean in 2000-2001. Only five of the fourteen position classifications met or exceeded the AAU market. Functional specialists reached 101 percent of the AAU mean in 2001-2002. Reference librarians with five to nine years of experience reached 111 percent of the mean and those

\begin{tabular}{|c|c|c|c|c|c|}
\hline \multicolumn{6}{|c|}{$\begin{array}{c}\text { TABLE } 3 \\
\text { Market Equity by Position Classification } \\
\text { University of Colorado at Boulder versus Public AAU Libraries Mean Salaries } \\
\text { Selected Continuing Positions, 1996-1997 through 2000-2001 } \\
\end{array}$} \\
\hline & 1996-97 & 1997-98 & 1998-99 & 1999-00 & $2000-01$ \\
\hline \multicolumn{6}{|l|}{ Associate Director } \\
\hline AAU Mean & $\$ 76,690$ & $\$ 80,161$ & $\$ 82,146$ & $\$ 86,532$ & $\$ 93,526$ \\
\hline CU Mean with Market Equity & $\$ 62,101$ & $\$ 67,144$ & $\$ 72,517$ & $\$ 77,602$ & $\$ 82,843$ \\
\hline CU Percentage of AAU Mean & $81.0 \%$ & $83.8 \%$ & $88.3 \%$ & $89.7 \%$ & $88.6 \%$ \\
\hline CU Mean without Market Equity & $\$ 62,101$ & $\$ 63,591$ & $\$ 65,410$ & $\$ 66,941$ & $\$ 68,628$ \\
\hline \multicolumn{6}{|l|}{ Head, Branch } \\
\hline AAU Mean & $\$ 52,393$ & $\$ 52,393$ & $\$ 55,940$ & $\$ 59,520$ & $\$ 61,661$ \\
\hline CU Mean with Market Equity & $\$ 45,194$ & $\$ 48,047$ & $\$ 51,330$ & $\$ 54,530$ & $\$ 57,833$ \\
\hline CU Percentage of AAU Mean & $86.3 \%$ & $91.7 \%$ & $91.8 \%$ & $91.6 \%$ & $93.8 \%$ \\
\hline CU Mean without Market Equity & $\$ 45,194$ & $\$ 46,374$ & $\$ 47,985$ & $\$ 49,512$ & $\$ 51,142$ \\
\hline \multicolumn{6}{|l|}{ Department Head, Rare Books } \\
\hline AAU Mean & $\$ 57,509$ & $\$ 60,284$ & $\$ 63,760$ & $\$ 64,801$ & $\$ 73,611$ \\
\hline CU Mean with Market Equity & $\$ 49,566$ & $\$ 52,983$ & $\$ 57,370$ & $\$ 61,219$ & $\$ 64,868$ \\
\hline CU Percentage of AAU Mean & $86.2 \%$ & $87.9 \%$ & $90.0 \%$ & $94.5 \%$ & $88.1 \%$ \\
\hline CU Mean without Market Equity & $\$ 48,017$ & $\$ 50,900$ & $\$ 53,203$ & $\$ 54,969$ & $\$ 56,534$ \\
\hline \multicolumn{6}{|l|}{ Functional Specialist } \\
\hline AAU Mean & $\$ 42,175$ & $\$ 43,621$ & $\$ 45,136$ & $\$ 45,938$ & $\$ 48,127$ \\
\hline CU Mean with Market Equity & $\$ 37,951$ & $\$ 40,224$ & $\$ 43,191$ & $\$ 45,918$ & $\$ 48,481$ \\
\hline CU Percentage of AAU Mean & $90.0 \%$ & $92.2 \%$ & $95.7 \%$ & $100.0 \%$ & $100.7 \%$ \\
\hline CU Mean without Market Equity & $\$ 37,951$ & $\$ 39,037$ & $\$ 40,762$ & $\$ 42,235$ & $\$ 43,627$ \\
\hline \multicolumn{6}{|l|}{ Reference } \\
\hline \multicolumn{6}{|l|}{ 10-14 Years Experience } \\
\hline AAU Mean & $\$ 38,386$ & $\$ 40,031$ & $\$ 41,760$ & $\$ 43,568$ & $\$ 44,909$ \\
\hline CU Mean with Market Equity & $\$ 31,253$ & $\$ 36,513$ & $\$ 40,459$ & $\$ 45,280$ & $\$ 49,172$ \\
\hline CU Percentage of AAU Mean & $81.4 \%$ & $91.2 \%$ & $96.9 \%$ & $103.9 \%$ & $109.5 \%$ \\
\hline CU Mean without Market Equity & $\$ 31,253$ & $\$ 34,370$ & $\$ 36,173$ & $\$ 38,851$ & $\$ 40,600$ \\
\hline \multirow{2}{*}{\multicolumn{6}{|c|}{$\begin{array}{l}\text { Reference } \\
\text { 5-9 Years Experience }\end{array}$}} \\
\hline & & & & & \\
\hline AAU Mean & $\$ 35,300$ & $\$ 37,004$ & $\$ 37,390$ & $\$ 38,939$ & $\$ 40,490$ \\
\hline CU Mean with Market Equity & $\$ 30,160$ & $\$ 33,078$ & $\$ 37,987$ & $\$ 40,937$ & $\$ 44,962$ \\
\hline CU Percentage of AAU Mean & $85.4 \%$ & $89.4 \%$ & $101.6 \%$ & $105.1 \%$ & $111.0 \%$ \\
\hline CU Mean without Market Equity & $\$ 30,160$ & $\$ 32,894$ & $\$ 37,619$ & $\$ 40,385$ & $\$ 44,226$ \\
\hline
\end{tabular}


with ten to fourteen years of experience reached 109 percent. Table 3 selectively represents these data with the bolded percentages indicating the distances from the AAU market at the beginning and end of the program.

Total compensation, however, is not only composed of market equity, but also includes annual merit compensation increases. During the four years of the market equity program, annual merit compensation at CUB Libraries typically represented between one-third and one-half of the total compensation. During the market equity program period, merit compensation to CUB librarians averaged three percent. The average ARL increase for the same period, as cited earlier, was about four percent. For the AAU libraries (excluding CUB), the average increase in median salary was 4.06 percent. Although significant, a one percent increase in merit compensation would not have been sufficient to bring salaries to market levels. However, lower annual merit compensation would contribute to salaries lagging behind market. That so few continuing classifications reached the AAU mean, and that low annual merit increases probably do not explain the deficit, suggests that dividing the equity over four years undermined the program.

However, there is compelling evidence that contradicts such a conclusion. Even if all \$300,000 in market equity funds had been distributed in 1996-1997 rather than spread over four years, the 2000-2001 salaries would have been nearly the same. Associate directors, for example, earned, on average, \$63,473 in 1996-1997 and were deserving of $\$ 12,809$ in market equity. Had that been awarded as a single sum, the $1997-1998$ salary would have been $\$ 76,282$; and with proportional merit increases, the 2000-2001 salary would have increased to $\$ 83,115$, within a few dollars of the actual mean salary achieved of $\$ 82,843$. This is still far short of the 2000-2001 AAU mean salary of $\$ 93,526$, but it is nearly the same distance as the actual salary achieved when market equity was spread over four years. For the head, branch classification, had the total equity need of $\$ 6,246$ been funded in 1996-1997, salaries would have been immediately raised from $\$ 45,743$ to $\$ 51,989$. Given proportional salary increases, the mean head, branch salary would have risen to $\$ 58,609$ by $2000-2001$, nearly the same as the actual 2000-2001 salary realized of $\$ 57,833$. Similarly, for functional specialists, had their 1995-1996 salary been increased by $\$ 7,121$ to the market of $\$ 41,735$, their 2000-2001 mean salary would have been $\$ 47,555$. Again, this is nearly the same as the actual salary realized of $\$ 48,481$. This suggests that spreading the equity over four years did not significantly impact the final salaries.

Another possible explanation for why many salaries for continuing librarians did not achieve market is that the market itself changed. And, in fact, throughout the four-year period, market salaries did increase at different rates for different position classifications. The average salary increase of all AAU position classifications from 1996-1997 through 2000-2001 was 12 percent. That is, a classification with a market of $\$ 50,000$ in 1996-1997 would be earning $\$ 56,000$ in 2000-2001. However, specific increases varied greatly among classifications. Some increased at a higher rate than the average of 12 percent and others increased less than 12 percent. For example, the associate director's classification market increased nearly 22 percent; the head, branch classification market increased 18 percent; for rare books librarians it was 28 percent; for reference librarians with five to nine years of experience, it was a comparatively modest 14 percent. In fact, the CUB Libraries classifications that achieved market had relatively modest market increases. The functional specialist classification sustained only a 14 percent market increase, and reference librarians with ten to fourteen years of experience saw only a 16 percent increase.

Equity was being assigned year after year assuming that the distance between a classification and its market was a constant gap when, in fact, the market value of some positions was increasing at a much faster rate than it was for others. The most extreme cases of this were the rare books classifica- 
tion, the associate director classification, and the head, branch classification. None of these moved more than seven percent closer to their market simply because their market was increasing at a much higher rate than the average. This worked in reverse in some cases. For example, reference librarians with five to nine years of experience saw their salaries increase to 111 percent of the market because their equity awards were locked at a rate higher than their true market increased.

This implies that the CUB Libraries' application of market equity might have been improved had the distances between the AAU market and the CUB position classification salaries been recalculated each of the four years. By doing so, adjustments could have been made to the annual awards that more accurately reflected actual market positions. Although it is unlikely that more positions would have attained market, it might have more evenly distributed the available funds. Such an outcome might have been preferable to the uneven impact on salaries for the faculty who continued throughout the program. As it was implemented, there was no mechanism to make annual adjustments to the distribution. This analysis suggests that by not adjusting the equity distribution to annual market fluctuations, some position classifications were undercompensated and others were overcompensated. However, recalculating market annually might have been impractical as the national salary data would not always have been available in a timely manner and the potential for internal turmoil would have been too great.

\section{Conclusion}

When the University of Colorado administration committed $\$ 300,000$ for market equity increases to University Libraries, it was a sincere attempt to solve a significant recruiting and retention problem by raising salaries to the AAU market mean. As has been the practice in other institutions, the market equity funds were distributed over multiple years because of financial and political issues. Certainly, the infusion of mar- ket equity funds made a significant difference in the salaries of CUB librarians. When viewed in the context of the entire faculty, the project raised salaries to the AAU market. Even salaries of continuing librarians increased by an average of 10 percent to about 85 percent of the AAU market mean. Moreover, without the market equity infusion, the consequences could have been catastrophic, with many of the continuing libraries faculty falling to 20 percent below the AAU market. There were also notable successes in raising specific continuing classifications of faculty to market salaries. The functional specialists, reference librarians with five to nine years of experience, and reference librarians with ten to fourteen years of experience increased above market salary levels. In some cases, these continuing classifications of faculty began with large market deficits. For example, reference librarians with ten to fourteen years of experience went from $\$ 7,766$ below market to \$4,263 above market in 2000-2001.

But there also were notable failures to the program. The shift to a younger, entrylevel faculty had more impact than market equity in bringing overall CUB Libraries salaries to the AAU market mean. Those continuing faculty who achieved market equity levels, such as those cited above, did so primarily because the market increase for their classification was lower than the market increases for other positions. Finally, those classifications of librarians most in need of equity did not significantly increase in salary regardless of the equity application. The associate director classification was $\$ 12,809$ below the AAU mean in 1996 1997 and $\$ 10,683$ below the AAU mean in 2000-2001. Similarly, the rare books and computer systems classifications did not make significant gains toward the AAU mean. That some classifications achieved higher-than-market levels, many remained significantly lower, and one fell even further below the market underscores the dramatic market changes each classification underwent during those four years.

In the July 2000 JAL study, the authors predicted that by distributing the market equity funds over four years, CUB Librar- 
ies salaries would not rise to the 1995-1996 mean until the 1999-2000 academic year. This proved too simplistic a prediction. This study suggests that it was unlikely that distributing the market equity over four years had a significant impact on final salaries because the individual differences from the AAU market were nearly the same whether divided over four years or awarded all in the first year. Instead, the failure to achieve market can more likely be attributed to changes in the mar- ket rate of each position classification. That a handful of positions achieved market while most languished well below is not because market funds were distributed over four years but, rather, because there was far more market variation between position classifications than anticipated. An important point for future market equity distributions would be that better results might be realized if market distances are recalculated every year of the program with a corresponding award adjustment.

\section{Notes}

1. Scott Seaman, Nancy Carter, Carol Krissman, and David Fagerstrom, "Market Equity Tempered by Career Merit: A Case Study," Journal of Academic Librarianship 26 (July 2000): 225-32.

2. Maureen Pastine and Shirley McLean, "Pay Equities in Libraries," Bottom Line 7 (summer 1993): 7-12.

3. Jeanie Welch and Linda Dugger, "Suggested Guidelines for Salary Determination in an Academic Library," Journal of Academic Librarianship 14 (Jan. 1989): 366-71.

4. Fay Zipkowitz, "Jobs tight, Salaries Holding," Library Journal 117 (Oct. 15, 1992): 31-36.

5. Herbert Carson, "Beginner's Luck: A Growing Job Market," Library Journal 121 (Oct. 15, 1996): 29-30.

6. _— "Placements and Salaries, 1996: Counting on Technology," Bowker Annual 43 (1998): $355-67$.

7. Vicki Lovelady Gregory and Kathleen de la Pena McCook, "Breaking the \$30K Barrier," Library Journal 123 (Oct. 15, 1998): 32-38.

8. Mary Jo Lynch, “Librarians' Salaries: Barely Any Increase This Year," American Libraries 27 (Oct. 1996): 59-60; Vicki L. Gregory, "Beating Inflation Now: Placements and Salaries '98," Library Journal 124 (Oct. 15, 1999): 36-42; Vicki L. Gregory and Sonia Ramirez Wohlmuth, "Placements and Salaries 1999: Better Pay, More Jobs," Bowker Annual 46 (2001): 322-35.

9. Gordon Fretwell, ARL Annual Salary Survey 1989 (Washington, D.C.: Association of Research Libraries, 1990), 36.

10. Mary Jo Lynch, "Librarians' Salaries: Small Increases Like Everyone Else," American Libraries 23 (Oct. 1992): 784; Gregory, "Beating Inflation Now"; Mary Jo Lynch, "Librarians' Salaries Up 4.3\% Reflecting National Mean," American Libraries 31 (Oct. 2000): 62+; Martha Kyrillidou, ARL Salary Survey Highlights (Washington, D.C.: Association of Research Libraries, 2002), 14.

11. Martha Kyrillidou and Karen Wetzel, ARL Annual Salary Survey 1999-2000 (Washington, D.C.: Association of Research Libraries, 2000), 26.

12. ——, "ARL Annual Salary Survey 2000-2001." Available online from http:// www.arl.org/stats/salary/2000-01/00intro.html. [Accessed 23 March 2003].

13. Gordon Fretwell and Sarah M. Pritchard, ARL Annual Salary Survey 1990 (Washington, D.C.: Association of Research Libraries, 1991), 19.

14. Martha Kyrillidou and Kimberly Maxwell, ARL Annual Salary Survey 1996-97 (Washington, D.C.: Association of Research Libraries, 1996), 29.

15. These institutions are: University of Arizona; University of California, Berkeley; University of California, Irvine; University of California, Los Angeles; University of California, San Diego; University of California, Santa Barbara; University of Indiana; University of Florida; University of Illinois, Urbana; University of Kansas; University of Maryland, College Park; Iowa State; University of Michigan, Ann Arbor; Michigan State; University of Minnesota, Twin Cities; University of Missouri, Columbia; University of Nebraska, Lincoln; University of North Carolina, Chapel Hill; Ohio State; University of Oregon; Pennsylvania State; University of Pittsburgh; Purdue; State University of New York, Buffalo; University of Texas, Austin; University of Washington; and University of Wisconsin, Madison.

16. Seaman, et al., "Market Equity Tempered by Career Merit."

17. Martha Kyrillidou and Mark Young, ARL Annual Salary Survey 2001-02 (Washington, D.C.: Association of Research Libraries, 2002), 26. 